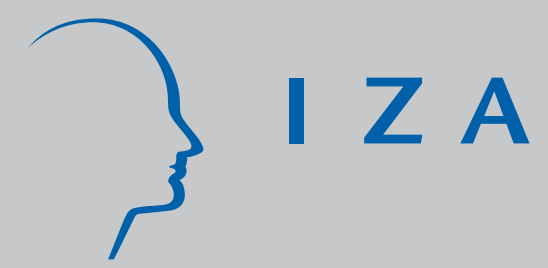

IZA DP No. 8510

The Productivity Consequences of Political Turnover: Firm-Level Evidence from Ukraine's Orange Revolution

John S. Earle

Scott Gehlbach

September 2014

Forschungsinstitut zur Zukunft der Arbeit Institute for the Study of Labor 


\title{
The Productivity Consequences of Political Turnover: Firm-Level Evidence from Ukraine's Orange Revolution
}

\author{
John S. Earle \\ George Mason University, \\ Central European University and IZA \\ Scott Gehlbach \\ University of Wisconsin-Madison \\ Discussion Paper No. 8510 \\ September 2014 \\ IZA \\ P.O. Box 7240 \\ 53072 Bonn \\ Germany \\ Phone: +49-228-3894-0 \\ Fax: +49-228-3894-180 \\ E-mail: iza@iza.org
}

\begin{abstract}
Any opinions expressed here are those of the author(s) and not those of IZA. Research published in this series may include views on policy, but the institute itself takes no institutional policy positions. The IZA research network is committed to the IZA Guiding Principles of Research Integrity.

The Institute for the Study of Labor (IZA) in Bonn is a local and virtual international research center and a place of communication between science, politics and business. IZA is an independent nonprofit organization supported by Deutsche Post Foundation. The center is associated with the University of Bonn and offers a stimulating research environment through its international network, workshops and conferences, data service, project support, research visits and doctoral program. IZA engages in (i) original and internationally competitive research in all fields of labor economics, (ii) development of policy concepts, and (iii) dissemination of research results and concepts to the interested public.
\end{abstract}

IZA Discussion Papers often represent preliminary work and are circulated to encourage discussion. Citation of such a paper should account for its provisional character. A revised version may be available directly from the author. 
IZA Discussion Paper No. 8510

September 2014

\section{ABSTRACT}

\section{The Productivity Consequences of Political Turnover: Firm-Level Evidence from Ukraine's Orange Revolution}

We examine the impact of political turnover on economic performance in a setting of largely unanticipated political change and profoundly weak institutions: the 2004 Orange Revolution in Ukraine. Exploiting census-type panel data on over 7,000 manufacturing enterprises, we find that the productivity of firms in the regions most supportive of Viktor Yushchenko increased by more than 15 percentage points in the three years following his election, relative to that in the most anti-Yushchenko regions. We conclude that this effect is driven primarily by particularistic rather than general economic policies that disproportionately increased output among large enterprises, government suppliers, and private enterprises - three types of firms that had much to gain or lose from turnover at the national level. Our results demonstrate that political turnover in the context of weak institutions can have substantial distributional effects that are reflected in economic productivity.

JEL Classification: H32, D72, P26

Keywords: political connections, firm behavior, voting, transition

Corresponding author:

John S. Earle

School of Public Policy

George Mason University

3351 Fairfax Drive, MS 3B1

Arlington, VA 22201

USA

E-mail: earle@gmu.edu 
Political turnover disrupts connections between political and economic actors, produces changes in economic policy, and creates uncertainty, with potential consequences for economic performance. Beginning with the seminal work of Londregan and Poole (1990), Barro (1991), and Alesina et al. (1996), the possible impact of turnover on economic performance has been incorporated into cross-country empirical work on growth and investment through the inclusion of measures of political instability. More recently, scholars working on the economic consequences of political connections have examined the differential impact of political turnover on politically connected firms (e.g., Fisman, 2001; Fisman et al., 2012; Ferguson and Voth, 2008).

Of course, not all turnover is bad for economic performance. Bates and Block (2013), for example, demonstrate that total factor productivity growth is greater in African countries with competitive executive elections - that is, in countries in which peaceful transfers of power are likely. But the potential for political turnover to negatively affect economic performance for some actors, even as it improves it for others, is especially large in countries with weak institutions (North, Wallis and Weingast, 2009, p. 263). In such countries, political turnover can redistribute connections in a way that makes doing business harder for some firms and easier for others; weak property rights can leave firms vulnerable to expropriation when political patrons disappear. Moreover, a relative absence of checks and balances implies that changes in power can produce large swings in economic policy, while a lack of transparency increases opportunities for discrimination and favoritism.

We examine the impact of political turnover on economic performance in a setting of largely unanticipated turnover and profoundly weak institutions: the 2004 Orange Revolution in Ukraine. Our research design exploits a sharp divide in Ukraine's political-economic geography. The old regime was tied to business owners and managers in the eastern part of the country, whereas Viktor Yushchenko, who successfully contested power in 2004 at the ballot box and in the street, had his political base in the west. The Orange Revolution dramatically shifted the geographic balance of power from the first region to the second. We 
thus identify the impact of political turnover on economic performance through a differencein-differences design that compares the relative performance of pro- and anti-Yushchenko regions before and after 2004. ${ }^{1}$

Our empirical focus is firm productivity, which we estimate with census-type panel data on over 7,000 Ukrainian manufacturing enterprises. The idea that turnover can affect productivity is not new (see, e.g., Alesina and Perotti, 1996), but most existing work focuses on investment or profits, which have a more tangential relationship to economic welfare. An important exception is the work of Haber and Razo (1998; see also Haber, Razo and Maurer, 2003), who document the impact of the Mexican Revolution on productivity in a single sector (the cloth textile industry). To our knowledge, there is no analogous work that identifies the differential impact on productivity in sectors or regions differently affected by political turnover. The few papers that examine the relationship between political connections and productivity do so in a cross-sectional setting (e.g., Guriev and Rachinsky, 2005; Faccio, 2010; Desai and Olofsgard, 2011), so that the impact of changes to connections cannot be identified.

We find a sharp divergence after the Orange Revolution in the relative performance of firms between regions supportive of and opposed to Viktor Yushchenko. Our results suggest that the productivity of firms in the most pro-Yushchenko regions increased by more than 15 percentage points in the three years following the Orange Revolution, relative to that in the most anti-Yushchenko regions. Guided by a discussion of the various channels through which political turnover might affect productivity, we conclude that this effect is driven primarily by particularistic rather than general economic policies that disproportionately increased output among large enterprises, government suppliers, and private enterprises - three types of firms that had much to gain or lose from turnover at the national level.

Our results demonstrate that political turnover in a context of weak institutions can

\footnotetext{
${ }^{1}$ In related work, Malesky and Samphantharak (2008) exploit differences in gubernatorial turnover to test theories about the predictability of corruption.
} 
have substantial distributional effects that are reflected in economic productivity. The next section describes the channels through which such effects might operate.

\section{Political turnover and firm behavior}

Political turnover can lead to changes in firm behavior through various channels. A new government may change official policies towards business, including taxes and regulations that affect the incentives of firms to invest, eliminate redundant labor and capital, refrain from asset stripping, seek out new markets, create new product lines, and otherwise take costly actions with the potential to improve firm performance. Political turnover may also be accompanied by changes in more subtle practices involving enforcement, corruption and predation, which may be less easily observed but matter just as much if not more for the business environment (e.g., Fisman and Svensson, 2007). Political turnover may also raise uncertainty to the extent that either the objectives of the new leaders, or their ability to implement their goals, are unknown; indeed, some economists have recently argued that uncertainty of the latter sort creates a substantial drag on U.S. economic growth (e.g., Baker, Bloom and Davis, 2013) These channels are economy-wide in their impacts, and not necessarily discriminatory across different groups or regions. For instance, any change that reduces the overall security of property rights will have a general tendency to reduce investment, growth, and productivity throughout the economy.

Other channels are more likely to lead to differential effects. Particular firms or those in particular regions or sectors may gain political connections while others lose them. Especially when institutions are weak, such connections can provide various economic benefits, including direct subsidies, preferential access to inputs (including credit from state-controlled banks), and government contracts. The reallocation of contracts following political turnover may be particularly attractive because it is less transparent than open subsidies or changes to legislation and regulations.

Policies that superficially seem to be general may also have differential effects. For 
example, trade liberalization will hurt import-competing sectors while it benefits users of imported raw materials and intermediates, as well as consumers more generally. To the extent that firms in such sectors are are distributed non-uniformly across space, this may result in regional differences in the response to turnover. Political turnover that leads to efforts to redress past discrimination and favoritism will also have differential effects on the winners and losers from these changes.

To the extent that differential effects are driven by particularistic policies, or the removal of such, these may be more evident among some types of firms than others. Large firms, for example, may be more likely than small firms to rely on ties to national politicians for support and protection, implying that channels working through political connections would be reflected in size-related differences. (Large firms may also benefit disproportionately from general improvements in the business climate because of financial resources or diversification. Further below we discuss the empirical implications of these alternative perspectives.) Similarly, business groups with direct representation in government (e.g., owners or managers who sit in parliament) may be more sensitive to changes in national political coalitions.

Heterogeneous effects may also be reflected in other firm characteristics. Firms in sectors that are government suppliers may be more reliant on political connections, especially when an absence of transparency and rule of law allows for favoritism in awarding contracts. In an environment of economic transition, the incentives of private firms may also be more sensitive to political turnover. Policies to reverse privatizations conducted by previous governments can encourage firms to delay restructuring, especially if the original allocation of property rights was questionable legally or ethically. ${ }^{2}$ Alternatively, privately owned firms may be more active in restructuring and investment; such firms will be more reliant on a "helping hand" for complementary infrastructure and more exposed to the "grabbing hand" of obstructive or predatory government behavior (Frye and Shleifer, 1997; Brown, Earle and

\footnotetext{
${ }^{2}$ Frye (2006) shows that "good works" can reduce the threat of renationalization for such firms.
} 
Gehlbach, 2009).

Finally, the various channels through which political turnover affects firm performance may be reflected in the components of productivity, which in general is defined as the ratio of output to inputs. Threats to property rights should discourage investment, though effects on other variables are also possible: most any productivity-enhancing change is an "investment" - a costly action with an uncertain return - and thus subject to the same con-

siderations as investments in physical capital. Improvements in the business climate, which can be conceptualized as the elimination of transaction costs, should work in the opposite direction. Last, any impact that operates through increased business opportunities, such as the reallocation of government contracts, should be reflected at the output margin. Whether inputs are similarly affected depends on the extent to which firms are already operating at capacity.

We return to these channels and provide empirical evidence on their relative importance further below, after describing our data, empirical strategy, and baseline estimates of the impact of political turnover on productivity. First, however, we discuss the political context for our analysis of these issues.

\section{Political context}

In late December 2004, following a tumultuous month of street protests and a do-over election, Viktor Yushchenko was declared the president-elect of Ukraine. The events of that period are commonly known as the Orange Revolution.

The seeds of the Orange Revolution were planted in 2002, when Yushchenko's Our Ukraine party won a plurality in national voting for the Rada, Ukraine's parliament. This strong showing positioned Yushchenko, a former central banker and the prime minister from December 1999 to April 2001, as the opposition favorite to contest power in 2004 against Prime Minister Viktor Yanukovich, the chosen successor of incumbent President Leonid Kuchma. Although Yushchenko was initially given little chance of winning the presidency, 
the "mood gradually changed during the long election campaign" (Kuzio, 2006, p. 46). The growing fear during 2004 of a Yushchenko victory would lead to his poisoning in September at the probable hands of Yanukovich's political operatives, and subsequently to massive electoral fraud to secure Yanukovich's victory in a runoff election on November 21. The popular unrest that followed, modeled to some extent on earlier "color revolutions" in the postcommunist region (Beissinger, 2007; Tucker, 2007; Finkel and Brudny, 2013), ultimately led to the do-over election that catapulted Yushchenko to the presidency. ${ }^{3}$

Ukraine under Kuchma was a paradigmatic case of "patronal presidentialism," in which the president "wields not only the powers formally invested in the office but also the ability to selectively direct vast sources of material wealth and power outside of formal institutional channels" (Hale, 2005, p. 138). During the latter years of his reign, Kuchma utilized these powers in return for the support of a narrow business elite drawn primarily from the ethnically Russian east of the country. ${ }^{4}$ As in other postcommunist countries (Gehlbach, Sonin and Zhuravskaya, 2010), the influence of these business groups was cemented through representation in official government positions: using data that we describe further below, Gorodnichenko and Grygorenko (2008) report that in 2002 over one-quarter of large firms in eastern Ukraine belonged to a business group with a representative in parliament or government, far in excess of the ratio elsewhere.

The regional divide was exacerbated by Kuchma's choice of successor, as Yanukovich was closely associated with mining and steel interests in the southeastern region of Donetsk. His Regions of Ukraine was the most prominent example of the parties of power that served as "political kryshy [roofs] for corrupt, oligarchic and regional interests, not for clearly defined ideologies" (Kuzio, 2005, p. 356). Fearful of loss of access under Yushchenko (in the words

\footnotetext{
${ }^{3}$ For an excellent chronicle of these events, see Wilson (2005).

${ }^{4}$ Viktor Medvedchuk, the head of Kuchma's presidential administration, led a business group based in Kyiv, but this group had few production assets of the sort included in our dataset.
} 


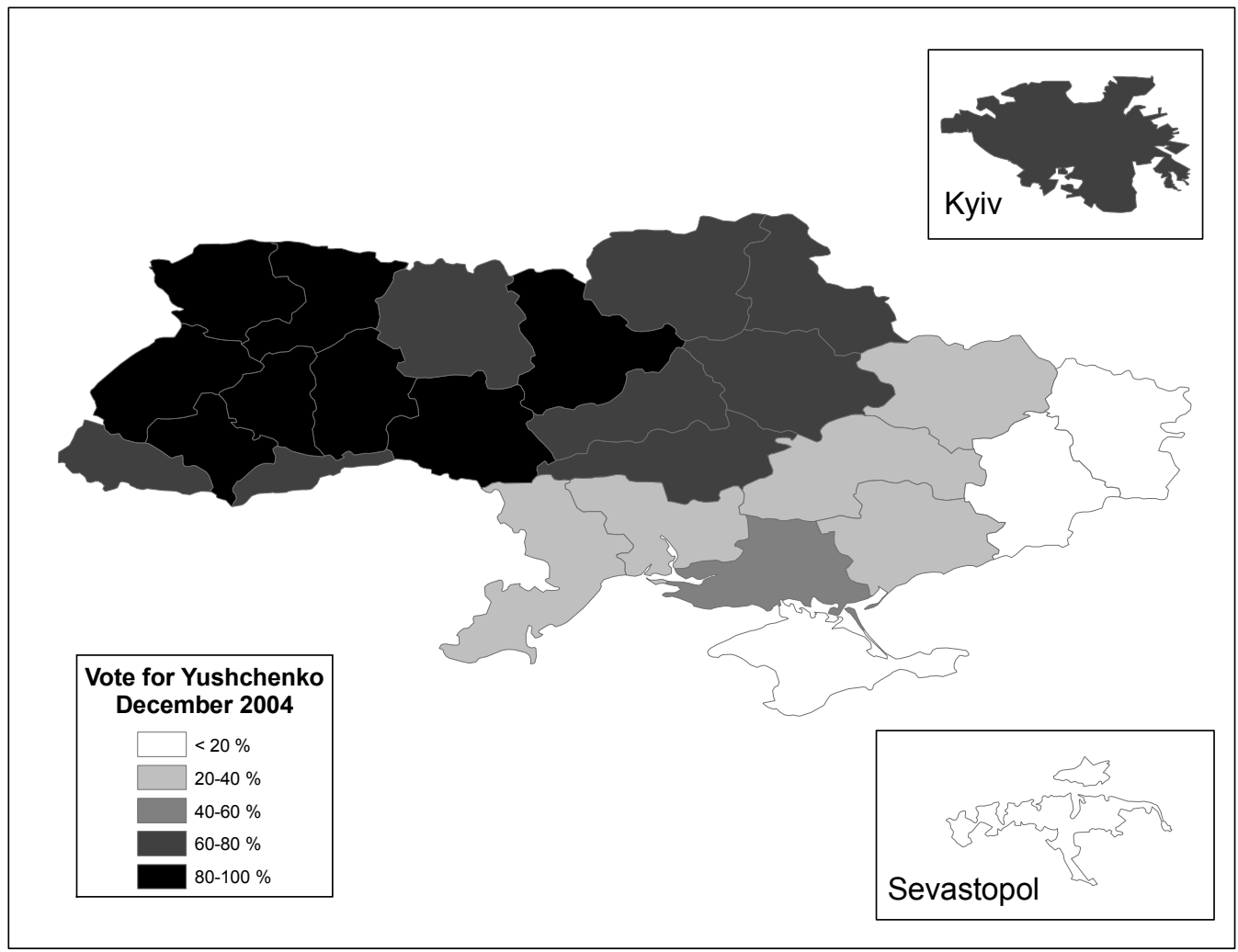

Figure 1: Voting in Ukraine's 2004 presidential election

of one analyst, reputational concerns make it "difficult to move from one cart to another" 5 ), and in some cases perhaps sharing Yanukovich's views on language issues and policy toward Russia and the West, these eastern businessmen spent generously on the 2004 election and mobilized their workers to vote for Yanukovich. ${ }^{6}$

As Figure 1 illustrates, voting in the 2004 elections was highly polarized around a regional divide between the ethnically Ukrainian west and Russian east: there are very few regions

${ }^{5}$ Interview with Jorge Zukoski, American Chamber of Commerce in Ukraine, June 2010. This point was also stressed in an interview with Anna Derevyanko, European Business Association, June 2010.

${ }^{6}$ Estimates of total campaign expenditures in 2004 exceed one percent of GDP (Åslund, 2006, p. 20). For evidence of various forms of electoral fraud in Ukraine's 2004 election, see Myagkov, Ordeshook and Shakin (2009). 
that are not either strongly pro-Yushchenko or strongly pro-Yanukovich. Yushchenko's political base was in the most western, historically Hapsburg part of the country (Clem and Craumer, 2005), and he owed nothing to the men who had financed the campaign against him. Upon taking power, Yushchenko named Yulia Tymoshenko, an oligarch-turned-populist who was one of Ukraine's savviest political operators, to head a short-lived government that was notable for the absence of easterners. Just as important, Yushchenko replaced every one of Ukraine's regional leaders, exercising the power of the president to appoint governors. These representatives of presidential authority play a key role in directing federal resources and allocating land and permits to local businesses; they consequently have enormous (and lucrative) influence over the fortunes of enterprises in their regions. ${ }^{7}$

In addition to these personnel changes, Ukraine's new leaders took various actions that threatened the eastern economic order. A series of investigations were launched against eastern businessmen, including the Donetsk industrialist Rinat Akhmetov, Ukraine's richest man, who temporarily fled the country in response to an inquiry into his connections with organized crime (Katchanovski, 2008). In addition, a noisy campaign in favor of "reprivatization" (i.e., nationalization and subsequent privatization of previously privatized enterprises) targeted many of the eastern businessmen who had acquired assets under Kuchma on the cheap (Paskhaver and Verkhovodova, 2007). The threat was credible, given the overwhelming majority of Ukrainians who were in favor of revising privatization (Åslund, 2009, pp. 206207; see also Denisova et al., 2009). In the end, only two previously privatized enterprises were seized by authorities, but the perceived threat to property rights has been blamed for the collapse in GDP growth that followed the Orange Revolution (Åslund, 2005). ${ }^{8}$ Finally,

\footnotetext{
${ }^{7}$ Interviews with Jorge Intriago, Ernst and Young, and Jorge Zukoski, American Chamber of Commerce in Ukraine, June 2010.

${ }^{8}$ As suggested in an interview with Dmitro Sologub, Raiffeisen Bank Aval, June 2010, fluctuations in world metals prices may have also played a role. Our identification strategy corrects for any such industry-specific shocks.
} 
the elimination of special economic zones in 2005 eliminated an important instrument of tax evasion for some firms in Donetsk. ${ }^{9}$

As discussed in the previous section, events such as these can have various effects on firm performance, some of which may be distributional in nature. Given the strongly regional character of the Orange Revolution, in the context of presidential authority exercised at the regional level through gubernatorial appointments, our emphasis is on differential changes in the productivity of firms located in Yushchenko and Yanukovich regions, respectively. In the following section, we describe the data used to estimate such changes.

\section{Data}

Our research design employs a multilevel approach, with firms nested in 27 regions (oblasti) of Ukraine. Our firm-level data are collected by the Ukrainian State Statistics Service (Derzhkomstat) and its Soviet-era predecessor. The primary source is industrial-enterprise registries, which include all industrial firms with more than 100 employees, plus those that are more than 25 percent owned by the state and/or by legal entities that are themselves included in the registry. Once firms enter the registries, they typically continue to report even if the original conditions for inclusion are no longer satisfied. The data thus correspond to the "old" sector of firms (and their successors) inherited from the Soviet system. We supplement the registry data with balance-sheet data and information from the State Property Committee and State Securities Commission, all linked over time using a firm identifier (OKPO) to construct a panel.

The resulting database includes measures of Output, Employment, Capital stock, and ownership, as well as industry affiliation and regional location. With respect to ownership, we classify firms as Domestic private if the state holds less than 50 percent of the shares and domestic private shareholders own more than foreigners; the firm is classified as Foreign private if the state holds less than 50 percent of the shares and foreign shareholders own

\footnotetext{
${ }^{9}$ Interview with Andriy Servetnuk, Deloitte and Touche, June 2010.
} 


\section{Table 1: Firm-level variables and summary statistics}

\begin{tabular}{lcccc}
\hline & 1992 & 1997 & 2002 & 2007 \\
\hline Output & 68 & 28 & 38 & 77 \\
& $(481)$ & $(275)$ & $(389)$ & $(665)$ \\
Employment & 756 & 544 & 351 & 331 \\
& $(1,814)$ & $(1,544)$ & $(1,568)$ & $(1,615)$ \\
Capital stock & 34 & 42 & 35 & 66 \\
& $(640)$ & $(646)$ & $(337)$ & $(542)$ \\
Domestic private & 0.000 & 0.552 & 0.742 & 0.767 \\
Foreign private & 0.000 & 0.002 & 0.009 & 0.000 \\
\hline Number of firms & 5,667 & 4,999 & 5,189 & 3,813 \\
\hline
\end{tabular}

Notes: Means and standard deviations. Capital and output are expressed in constant 2002 prices: millions of hryvnias. Output equals the value of gross output net of VAT and excise taxes. Employment equals the average number of registered industrial production personnel, which includes non-production workers but excludes "nonindustrial" employees who mainly provide employee benefits. Capital equals the average book value of fixed assets used in the main activity of the enterprise, adjusted for revaluations. The domestic and foreign private dummies are based on Derzhkomstat ownership classifications as of December 31st of the previous year.

more than domestic private owners. The residual category is state ownership. To maximize comparability and data quality, we exclude non-manufacturing sectors and non-profit organizations from the sample, and we include only firms that are state-owned on entry into the database. Finally, we retain firm-years in the sample only when they contain complete information, which does not reduce the sample appreciably. The resulting sample contains information on a panel of 7,684 enterprises, with 85,057 firm-year observations for 1989 and 1992-2007; data for 1990 and 1991 are not available. Table 1 presents summary statistics for several years in the panel.

For one exercise, we supplement these firm-level data with data on Oligarch ownership from Gorodnichenko and Grygorenko (2008). As described in that paper, a firm is considered to be "owned by an oligarch" if it belongs to a business group of at least three firms, at least one of which is a for-profit enterprise, where the parent entity coordinates the decisions of firms in the group and has a public representative in either the government or parliament. 


\section{Table 2: Region-level variables and summary statistics}

\begin{tabular}{lcccr}
\hline & Mean & SD & Min & Max \\
\hline Yushchenko vote & 0.583 & 0.308 & 0.042 & 0.960 \\
Russian ethnicity & 0.151 & 0.179 & 0.012 & 0.716 \\
Industrial production & 0.727 & 0.439 & 0.270 & 3.791 \\
Unemployment & 0.093 & 0.030 & 0.031 & 0.192 \\
(Log) small enterprises & 8.691 & 0.789 & 6.952 & 11.055 \\
(Log) exports & 5.902 & 1.255 & 3.581 & 9.274 \\
(Log) imports & 5.635 & 1.275 & 2.996 & 10.074 \\
$(\mathrm{Log})$ FDI & 4.283 & 1.429 & 0.042 & 8.700 \\
\hline
\end{tabular}

Unfortunately, the data are only available as a cross section, for 2002. Moreover, we are able to match the data in Gorodnichenko and Grygorenko with only 1,662 of the 7,684 enterprises in our dataset. Many of the unmatched firms are disproportionately small and/or never privatized and thus unlikely to be oligarch assets. We therefore set oligarch ownership equal to one if the firm is coded as such in Gorodnichenko and Grygorenko's dataset, and zero otherwise, which results in a coding of oligarch ownership for 243 firms, or slightly over three percent of our sample. This likely represents a lower bound on the actual level of oligarch ownership of firms in our dataset.

We use region-level data on the Yushchenko vote in the do-over runoff election of December 2004. As indicated in Table 2, which also includes summary statistics for other region-level variables, there is enormous variation in this variable, with Yushchenko receiving under 5 percent of the vote in the most pro-Yanukovich region (Donetsk) and more than 95 percent of the vote in the most pro-Yushchenko region (Ternopil). (The cities of Kyiv and Sevastopol are governed administratively as regions, and the data in this paper distinguish between these cities and the surrounding regions of Kyiv oblast and Crimea.) In some exercises we also use region-level aggregate economic data from the Ukrainian State Statistics Service: Industrial production (measured as an index, with $1990=1$ ), the Unemployment rate, the number of Small enterprises, the volume of Exports and Imports, and the level of Foreign direct investment (FDI), with the latter four variables measured in logs. 


\section{Empirical strategy}

We are interested in comparing changes in firm performance after the Orange Revolution in regions that were more or less supportive of Viktor Yushchenko, the ultimate victor in the 2004 presidential election. Our performance measure is multifactor productivity. ${ }^{10}$ Our baseline estimating equation is

$$
x_{j r s t}=f_{s}\left(k_{j r s t}, l_{j r s t}\right)+O_{t} V_{r} \gamma+\mathbf{Z}_{j r t} \boldsymbol{\mu}+\psi_{s t}+\mathbf{w}_{t} \boldsymbol{\alpha}_{j}+\eta_{j r s t},
$$

where $j$ indexes firms, $r$ indexes regions, $s$ indexes industries, and $t$ indexes years. The variable $x_{j r s t}$ is output, $k_{j r s t}$ is capital stock, and $l_{j r s t}$ is employment. We assume an unrestricted Cobb-Douglass production function $f_{s}$, which we allow to vary by manufacturing industry at the two-digit level, with 22 distinct sectors in our data.

Our difference-in-differences estimates are captured in the coefficient on the interaction term $O_{t} V_{r}$, where the dummy variable $O_{t}$ is an indicator for the Post-Orange Revolution period, set equal to 0 through 2004 and 1 thereafter, whereas the variable $V_{r}$ is the $\mathrm{Yu}$ shchenko vote in the do-over 2004 presidential election, as described in the previous section. The "direct effect" $O_{t}$ is absorbed by the industry-year fixed effects $\psi_{s t}$ : adopting vector notation,

$$
\mathbf{O}=\mathbf{I}_{2005} \mathbf{1}+\mathbf{I}_{2006} \mathbf{1}+\mathbf{I}_{2007} \mathbf{1}
$$

where $\mathbf{I}_{t}$ is the $N \times 22$ matrix of industry dummies for year $t$ (with $N$ the number of observations), and $\mathbf{1}$ is the $22 \times 1$ vector $(1, \ldots, 1)$. Similarly, the variable $V_{r}$ is absorbed by the firm fixed effects, as firm location is constant over time. The variable $\gamma$ in Equation 1

\footnotetext{
${ }^{10}$ Multifactor productivity is sometimes referred to as "total factor productivity," implying that all factors of production are included, but in practice some factors are unobserved. Our method takes into account firm-specific, time-varying levels of capital and employment; firmspecific constants (fixed effects) and trends; and a full set of industry-year interactions to control for differences in other factors.
} 
is our coefficient of interest: the differential effect of the Orange Revolution on multifactor productivity in regions more or less supportive of Yushchenko.

These estimates control for a great deal of heterogeneity over time and across firms, regions, and sectors. The vector $\mathbf{Z}_{j r t}$ includes various time-varying firm and regional characteristics; in some specifications, these include firm-level indicators for domestic private and foreign ownership at the end of year $t-1$. To avoid contaminating the estimates with industry-specific shocks or mismeasured relative prices, we include a full set of industry-year fixed effects, $\psi_{s t}$, so that comparisons are within industry-year cells. Finally, we correct for firm-specific heterogeneity through the term $\mathbf{w}_{t} \boldsymbol{\alpha}_{j}$, where $\mathbf{w}_{t}$ is a vector of aggregate time variables and $\boldsymbol{\alpha}_{j}$ a vector of firm-specific coefficients.

We consider two specifications of $\mathbf{w}_{t}$. The first defines $\mathbf{w}_{t}=1$, so that $\boldsymbol{\alpha}_{j}$ is a firm fixed effect; the second defines $\mathbf{w}_{t}=(1, t)$, with $\boldsymbol{\alpha}_{j}$ a firm-specific linear trend. We emphasize the second specification (a "random-growth" model) because it has a number of advantages. First, firm location is constant over time, so the inclusion of firm-specific trends implicitly captures region-specific trends. ${ }^{11}$ This helps to ensure that the difference-in-differences assumption of parallel trends across regions in the absence of treatment (conditional on covariates) is not violated. Similarly, the random growth model controls for different trend growth rates in productivity at the firm level. Second, as Brown, Earle and Telegdy (2006) show using similar data, the inclusion of firm-specific trends corrects for selection into type of ownership - state, domestic private, or foreign private - which will be an important issue when we focus on the differential effect of the Orange Revolution on private and state-owned enterprises. ${ }^{12}$

\footnotetext{
${ }^{11}$ Similarly, the inclusion of firm fixed effects implicitly captures region fixed effects. There
} are a very small number of cases in our data of firms changing location. For these firms, we define region as the modal region across years.

${ }^{12}$ The existence of long panels, as in our dataset, is especially important when including unit fixed effects and trends. Observe that any trends in firm performance are net of industry- 
Finally, the variable $\eta_{j r s t}$ is an idiosyncratic error. We report heteroskedasticity-robust standard errors that correct for clustering of errors at the region level, which, given that firms are nested in regions, also correct for arbitrary correlation of errors within time series for individual firms. ${ }^{13}$

\section{Difference-in-differences results}

The first two columns of Table 3 present our baseline difference-in-differences estimates for models with firm fixed effects and firm-specific trends, respectively. Although the estimated effect of the Orange Revolution is positive in both cases, it is larger and more precisely estimated in the second. Recalling that Yushchenko's vote share in the December 2004 election ranged from 0.04 to 0.96 (the density is mostly in the tails), the result in Column 2 implies a relative change in multifactor productivity after the Orange Revolution of approximately 17 percentage points in the most pro-Yushchenko region, compared to the most pro-Yanukovich region. Alternatively, a one-standard-deviation increase in Yushchenko vote (0.308) is associated with a relative increase in productivity of 6 percentage points. To put this in perspective, using data similar to those in this paper, Brown, Earle and Telegdy (2006) estimate that domestic privatization increases multifactor productivity (measured from the year before privatization to three years after) by 12 percent in Ukraine, versus 38,20 , and -8 percent in Romania, Hungary, and Russia, respectively. (We consider variation over time in the private-ownership effect further below, where we take advantage of an additional five

specific shocks, such as those associated with the economic transition and the output collapse in the 1990s, given the inclusion of industry-year fixed effects.

${ }^{13}$ Asymptotics for "cluster robust" standard errors are in the number of clusters, not number of observations, raising some questions about the interpretation of such standard errors when the number of clusters is small, as here. In practice, our choice is conservative, as the standard errors are substantially smaller if we correct for clustering at the region-year level or if we assume no correlation of errors across observations. 
years of data not available to Brown, Earle and Telegdy, 2006.) It is worth emphasizing that this result controls for industry-specific shocks, which may affect regions differentially given their different industrial compositions. The regression in Column 3 further includes controls for domestic private and foreign ownership; the estimated effect is nearly identical to that in Column 2.

The results in the first three columns are consistent with the hypothesis that the Orange Revolution had a differential effect on the formal and informal business environment for firms in different parts of the country. A related hypothesis, not mutually inconsistent, is that firms in particular regions benefited or suffered from Yushchenko's efforts to realign Ukraine with the West, a policy that came at the expense of relations with Russia. In principle, the shifting geopolitical environment could have disproportionately affected firms with actual or potential trade ties to the European Union and Russia. (Changing relations with the European Union and Russia may also have affected particular sectors, but any such impact would be captured by the industry-year fixed effects included in Equation 1.)

The specifications in Columns 4 and 5 explore this possibility by including interactions of the Orange Revolution dummy with various indicators for geographic location. The model in Column 4 divides Ukraine into four macro-regions - western, southern, eastern, and central (the excluded category) - following the typology in Clem and Craumer (2005). In Column 5, we interact the Orange Revolution dummy with indicators equal to one if the region borders Poland, Slovakia, Hungary, or Romania (Romania joined the European Union in 2007, but accession was nearly assured by the time of the Orange Revolution) or Russia, respectively. In each case, there is a relative productivity increase after the Orange Revolution for firms in the west of the country, holding constant Yushchenko's vote share, but the estimated effect of the Orange Revolution $\times$ Yushchenko vote interaction remains large and statistically significant. 


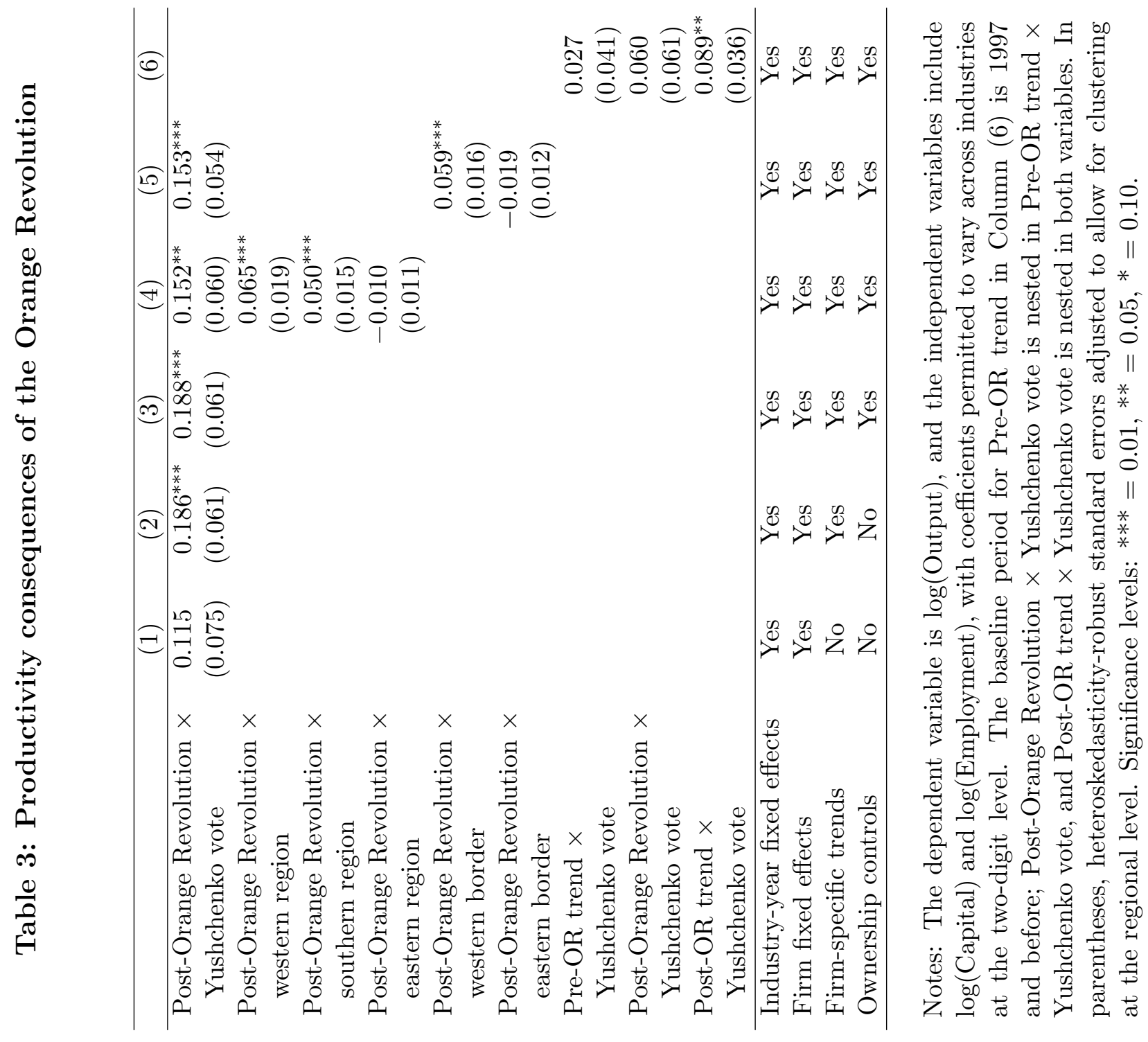


Finally, we explore the dynamics of the estimated treatment effect. To do so, we estimate the following variant of Equation 1:

$$
x_{j r s t}=f_{s}\left(k_{j r s t}, l_{j r s t}\right)+R_{t} V_{r} \varsigma+M_{t} V_{r} \omega+P_{t} V_{r} \varpi+\mathbf{Z}_{j r t} \boldsymbol{\mu}+\psi_{s t}+\mathbf{w}_{t} \boldsymbol{\alpha}_{j}+\eta_{j r s t},
$$

where $R_{t}$ (Pre-treatment) is equal to 0 for all years strictly before 1998 and equal to $t-1997$ for all subsequent years, $M_{t}$ (Treatment) is equal to 0 for all years strictly before 2005 and equal to 1 for all years thereafter, and $P_{t}$ (Post-treatment) is equal to 0 for all years strictly before 2006 and equal to $t-2005$ for all years thereafter. Each of these variables is interacted with Yushchenko vote, providing an estimate of the relationship between productivity trends and voting in the 2004 presidential election both before and after the Orange Revolution, relative to a baseline period prior to 1998. The presence of the second term allows for a discontinuity at 2005, the first year after the Orange Revolution.

Column 6 presents the estimated dynamics. There is a small, statistically insignificant relationship between political geography and productivity prior to the Orange Revolution. In contrast, the results imply a sizable but imprecisely estimated jump in relative productivity of 6 percentage points in 2005 between the most pro-Yushchenko and the most anti-Yushchenko region. The increase in 2005 is sustained through the years following the Orange Revolution, and each additional year leads to a larger, statistically significant divergence from pre-Orange Revolution trends. Thus, by 2007, the final year for which we have data, the estimated effect of Yushchenko vote on firm productivity is greater than that implied by the pre-Orange Revolution trend by $0.060+(2 \times 0.089)=0.238(\mathrm{SE}=0.111)$. These dynamic results are consistent with a causal effect of the Orange Revolution on firm performance. There is no evidence of a preexisting divergence/convergence between Yushchenko and Yanukovich regions: the treatment effect occurs post-treatment.

We also performed a number of other robustness checks, including dropping regions one at a time from the sample. The largest reduction in the estimated effect of the Orange Revolution comes from dropping Lviv, the center of Yushchenko's geographic base, though even in this case the estimated coefficient on Orange Revolution $\times$ Yushchenko vote is 0.152 , 
significant at $p=0.05$. We obtain qualitatively similar dynamic results using a baseline period of years prior to 1997 or 1999, rather than 1998. Further, the estimated dynamics with fixed effects but not firm-specific trends are similar to those in Column 6 - statistically indistinguishable from zero in the pre-treatment period (an estimated coefficient of -0.011 [SE $=0.022]$ on the pre-OR trend $\times$ Yushchenko vote interaction), and in fact stronger during the post-treatment period (an estimated coefficient of 0.085 [SE $=0.072]$ on the Post-OR $\times$ Yushchenko vote interaction, and an estimated coefficient of 0.108 [SE $=0.037$ ] on the Post-OR trend $\times$ Yushchenko vote interaction) .

Finally, as discussed in the online appendix, we estimate Equation 1 by two-stage least squares, where we instrument $O_{t} V_{r}$ on the interaction of the dummy variable $O_{t}$ and the Russian ethnicity of the region; the exclusion of this instrument is justified in part by the presence in Equation 1 of industry-year fixed effects, given that the ethnic composition of regions is correlated with industrial structure. As before, the estimated effect is substantively large and statistically significant, with a point estimate only slightly lower than that in Column 3. The results reported in this section prove to be quite robust.

\section{Interpretation and mechanisms}

In this section, we interpret and unpack the result documented in Section 5: an increase in multifactor productivity following the Orange Revolution in regions supportive of the winning candidate, relative to regions that supported the old regime. Subject to data limitations, our aim is to shed light on the theoretical channels that might account for this result. Following the discussion in Section 1, we explore three types of evidence: evidence of general versus particularistic policies; estimation of heterogeneous effects across types of firms that might be more or less vulnerable to political turnover; and exercises that separately examine the impact of the Orange Revolution on output, labor, and capital. 


\subsection{General versus particularistic policies}

In principle, the differing performance of Yushchenko and Yanukovich regions following the Orange Revolution could be a consequence not of particularistic policies, but of general policy changes that affected productivity in similar ways across regions, with differences in regional economic structure leading to different outcomes. Our empirical strategy rules out the most obvious such "composition effects": with a full set of of industry-year controls, any effects of the Orange Revolution that operate at the sector level should be held constant. Nonetheless, there could be other aspects of regional economic structure that create varying responses to identical policies.

Ideally, we would explore this possibility using data on other firm characteristics, the distributions of which are potentially heterogeneous at the regional level. Unfortunately, other than ownership, which we take up further below, our dataset does not include the variables necessary for this sort of analysis. We therefore turn to aggregate economic data, running regressions on regional panel data using the variables from the Ukrainian State Statistics Service summarized in Table 2. The general idea is to estimate the impact of the Orange Revolution on various macroeconomic outcomes in regions that are relatively more or less pro-Yushchenko. Given that our firm-level data are all manufacturing enterprises, we expect to find an effect on industrial production similar to that identified in the previous section. ${ }^{14}$ Beyond that, we look for effects on macroeconomic outcomes that might reflect general changes in economic policy refracted through regional differences in economic structure.

\footnotetext{
${ }^{14}$ To the extent that they are not, this could raise concerns about systematic bias in our firm-level data, as might occur if firms were differentially inclined to truthfully provide data to statistical authorities (Zhuravskaya, 2007).
} 


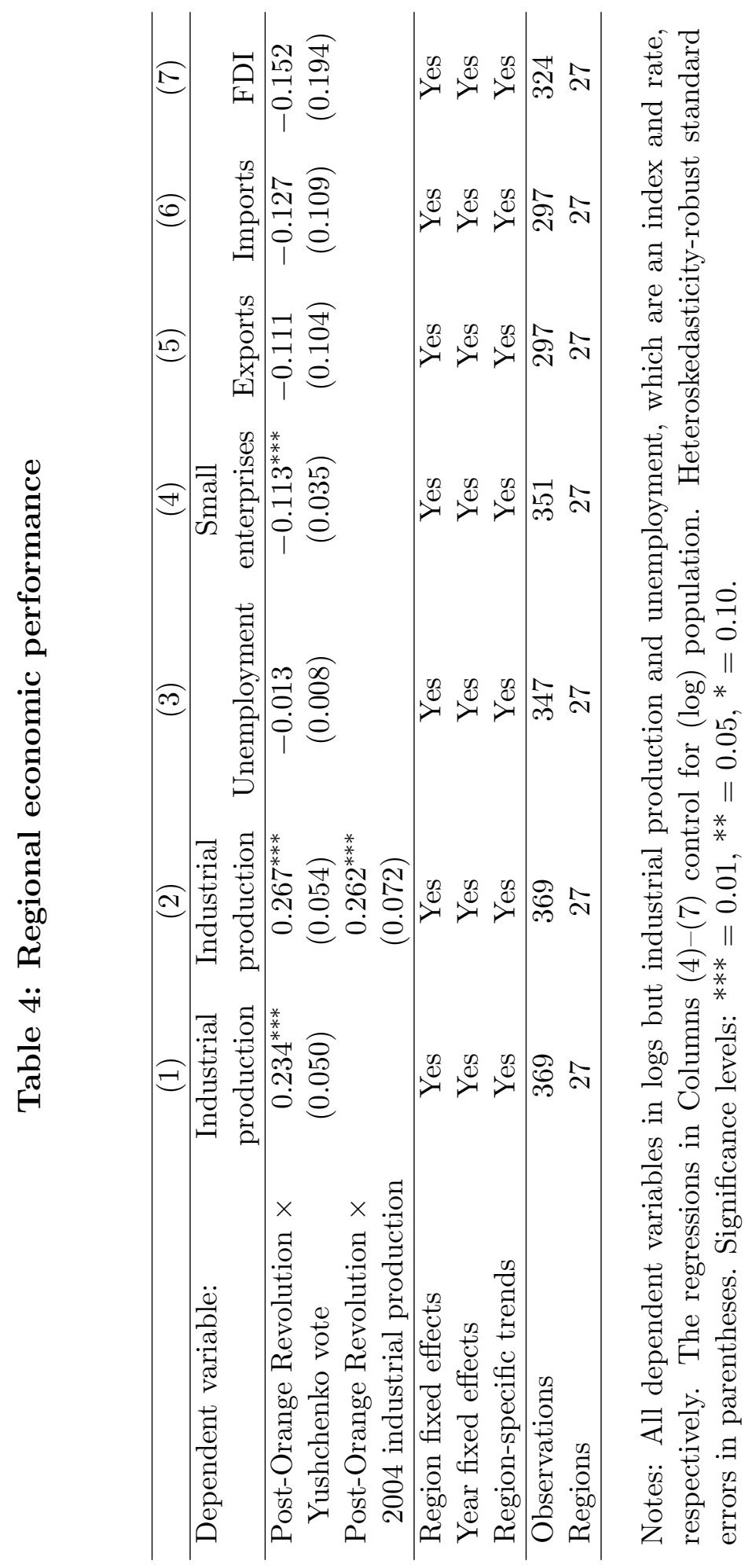


Table 4 presents results from this analysis. Column 1 shows that industrial production exhibits the same pattern following the Orange Revolution as firm-level productivity: an increase in regions supportive of Yushchenko, relative to those where Yanukovich did well. Further, Column 2 demonstrates that this is not the consequence of "catch-up" among those regions, largely concentrated in the western part of the country, that saw a larger output fall after the breakup of the Soviet Union. The estimated treatment effect is very similar when controlling for the interaction of Post-Orange Revolution and industrial production in 2004, as a proportion of production in 1990. (The estimated coefficient on the control is in fact positive, suggesting greater divergence from 1990 levels of industrial production.) Looking further, there is no significant effect on unemployment (Column 3), exports (Column 5), imports (Column 6), or foreign direct investment (Column 7). Only for small enterprises (Column 4) is the estimated impact of political turnover statistically significant, but with the opposite sign: pro-Yushchenko regions see a relative decline after 2004 in the number of small enterprises, this notwithstanding the active support provided during the Orange Revolution by small-business associations (Duvanova, 2013, pp. 79-80). All in all, we find no evidence of broader macroeconomic effects of the Orange Revolution that might explain the regional pattern identified with our firm-level data.

A related question is the following: Does the regional divergence represent a new policy of discrimination against Yanukovich regions, or is it rather the consequence of a leveling of the playing field, with firms in Yushchenko regions benefiting from support previously reserved for those in areas supportive of the old regime? The empirical strategy presented in Section 4 provides no leverage in answering this question, as the presence of fixed effects (and trends) precludes estimation of absolute changes in productivity following the Orange Revolution.

To make further progress, it is necessary to compromise on identification, sacrificing fixed effects and trends in order to gain some evidence for interpretation. We estimate

$$
x_{j r s t}=f_{s}\left(k_{j r s t}, l_{j r s t}\right)+O_{t} V_{r} \gamma+V_{r} \beta+\mathbf{Z}_{j r t} \boldsymbol{\mu}+\psi_{s t}+\eta_{j r s t},
$$


which differs from Equation 1 in that it omits the firm fixed effects and trends but includes Yushchenko vote as a direct term (while retaining industry-year interactions). Our estimate of the parameter $\beta(-0.297, \mathrm{SE}=0.112)$ suggests that firms operating in Yushchenko regions were on average less productive prior to the Orange Revolution than those in the same industry-year but operating in Yanukovich regions. The estimate of the treatment effect $\gamma(0.110, \mathrm{SE}=0.081)$, in turn, indicates a narrowing of the gap between Yushchenko and Yanukovich regions after 2004. Indeed, the sum of the two estimated coefficients is statistically indistinguishable from zero, suggesting that we cannot exclude the possibility of full convergence after the Orange Revolution. Our cautious interpretation of these results is that firms in Yushchenko regions benefited from support after the Orange Revolution previously reserved for firms from Yanukovich regions.

Some related evidence comes from quarterly surveys of business confidence in four regions conducted by the Institute for Economic Research and Policy Consulting in Ukraine, as presented in Figure 2. ${ }^{15}$ The most notable change after the Orange Revolution in late 2004 occurs in Lviv, the center of Yushchenko's geographic base. Although hardly conclusive, the fact the confidence rises in the one Western region and does not fall elsewhere is again suggestive that the improvement in Yushchenko regions did not necessarily come about at the expense of Yanukovich regions.

Taken together, these results suggest the following interpretation: Firms in Yushchenko regions lagged behind those in Yanukovich in the years prior to the Orange Revolution. After 2004, the gap between Yushchenko and Yanukovich regions narrowed considerably. The causes of the latter development seem not to be general changes in economic policy, but rather changes to how firms in various regions were treated by the state. To further explore this idea, we now proceed to examine heterogeneity in the response at the firm level.

\footnotetext{
${ }^{15}$ We are grateful to Oksana Kuziakiv of IERPC for providing these data.
} 


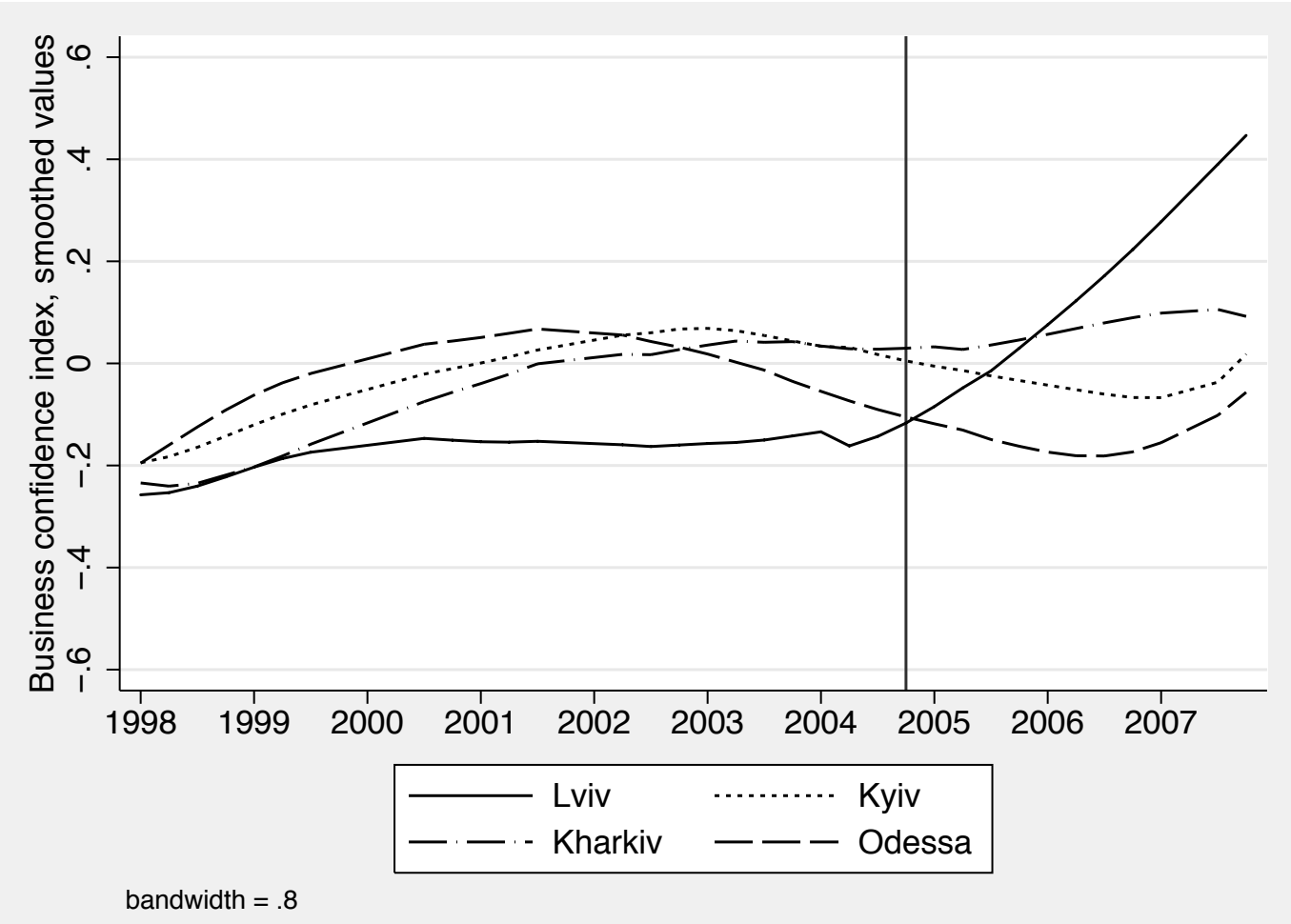

Figure 2: Business confidence over time in four Ukrainian regions

\subsection{Heterogeneous effects}

As discussed in Section 1, theories about how particularistic policies affect productivity may have observable implications if certain types of firms are more sensitive to political turnover. Our data allow us to distinguish among firms along four such dimensions. First, large firms may be more affected by who is in power at the national level than are small firms, which may be more likely to rely upon local politicians for political support and protection. Second, firms that are owned by politically connected business groups - "oligarchs" - may have more to gain or lose from a redistribution of political connections. Third, firms in sectors that are major government suppliers may be more vulnerable to disruptions of political connections. Finally, when institutions are weak, the productivity of private firms may be more responsive to turnover than the productivity of state-owned enterprises, either because the security of their private property rights depends on maintaining connections to the governing elite, or 
because they stand to gain more from an improved business environment.

Examining these hypotheses presents a number of identification and measurement issues. With respect to size, whether a firm is large or small is to some extent endogenous to decisions that affect productivity. Further, as discussed in Section 3, oligarch ownership is measured with considerable noise and is only available as a cross section (for 2002). More generally, ownership is not randomly assigned but the consequence of decisions made by government officials about which firms to target for privatization and by entrepreneurs about which firms to acquire. Finally, we observe sector but do not have direct data on government contracts.

We deal crudely with these problems for the effects of firm size, oligarch ownership, and government supplier. For size, we create the dichotomous variable Large, set equal to one if the firm's mean employment prior to 2004 is greater than 150, the conventional cutoff in the literature for small and medium-sized enterprises. The resulting variable is less sensitive to labor restructuring than the underlying employment measure. With respect to oligarch ownership, we create a dummy variable for firms that are oligarch-owned in 2002. Finally, we proxy for government supplier by creating the indicator Equipment supplier, set equal to one for firms with NACE code 29 (manufacture of machinery and equipment, which includes weapons and ammunition) or 35 (manufacture of other transport equipment, which includes rolling stock and aircraft but excludes automobiles). Although there may be many nongovernment suppliers in these sectors, the relative importance of government contracts is likely greater than for the full sample.

Table 5 provides results for size, oligarch ownership, and government supplier. The results in Column 1 indicate that the impact of the Orange Revolution is heterogeneous across size classes and regions. Relative to small firms, large firms see substantial productivity reductions in pro-Yanukovich regions following the Orange Revolution, whereas there is no significant effect of firm size in pro-Yushchenko regions. Put differently, where a firm is located is a predictor of productivity changes following the Orange Revolution only for large enterprises - a finding consistent with the hypothesis that large firms are more sensitive to 
Table 5: Size, oligarch ownership, and government supplier

\begin{tabular}{lccc}
\hline Post-Orange Revolution $\times$ & 0.034 & $0.178^{* *}$ & $0.148^{* *}$ \\
Yushchenko vote & $(0.086)$ & $(0.066)$ & $(0.062)$ \\
Post-Orange Revolution $\times$ & $-0.215^{* * *}$ & & \\
large & $(0.053)$ & & \\
Post-Orange Revolution $\times$ & $0.245^{* * *}$ & & \\
Yushchenko vote $\times$ large & $(0.080)$ & & \\
Post-Orange Revolution $\times$ & & -0.045 & \\
oligarch ownership & & $(0.142)$ & \\
Post-Orange Revolution $\times$ & & $(0.164$ & \\
Yushchenko vote $\times$ oligarch ownership & & & $0.236)$ \\
Post-Orange Revolution $\times$ & & & $(3.970)$ \\
equipment supplier & & & $0.228^{* *}$ \\
Post-Orange Revolution $\times$ & & & $(0.094)$ \\
Yushchenko vote $\times$ equipment supplier & Yes & Yes & Yes \\
\hline Industry-year fixed effects & Yes & Yes & Yes \\
Firm fixed effects & Yes & Yes & Yes \\
Firm-specific trends & Yes & Yes & Yes \\
Ownership controls & & & \\
\hline
\end{tabular}

Notes: The dependent variable is $\log$ (Output), and the independent variables include $\log ($ Capital $)$ and $\log ($ Employment $)$, with coefficients permitted to vary across industries at the two-digit level. In parentheses, heteroskedasticity-robust standard errors adjusted to allow for clustering at the regional level. Significance levels: ${ }^{* * *}=0.01,{ }^{* *}=0.05, *=0.10$.

political turnover at the national level because of the nature of their political connections. In contrast, if large firms benefited disproportionately (e.g., because of financial resources or diversification) from an improvement in the business climate that was constant across regions, we would expect to see a size effect that did not vary by Yushchenko vote.

Column 2 presents analogous results for models with our oligarch measure. The sign and magnitude of the coefficient suggest greater vulnerability of oligarch-owned firms to political turnover, but the estimated effect is statistically insignificant at conventional levels. The large standard errors are consistent with substantial heterogeneity in the behavior of oligarch-owned firms: perhaps some firms owned by oligarchs, who as defined here have formal representation in the government or parliament, find it comparatively easy to forge 
new connections following political turnover. When we include interactions with both size and oligarch ownership in a single equation, the qualitative results are essentially unchanged from those reported in Table 5: size clearly matters, whereas the effect of oligarch ownership is unclear.

Finally, Column 3 presents results for models with our proxy for government supplier. The regional effects identified in the previous section are substantially larger for firms in the equipment-supply sector. A natural question is whether this productivity effect is driven by changes at the output margin, as would be the case if government contracts were reallocated after the Orange Revolution to firms in regions supportive of Yushchenko. We take up this question in our "decomposition" exercises further below.

We now proceed to consider the differential response of private firms to the Orange Revolution. Given that private ownership is reliably measured for all firm-years in the sample, we have a clearer path to identification. We follow the two-step approach in Brown, Earle and Gehlbach (2009), which first uses firm-level panel data to estimate the effect of private ownership on multifactor productivity at the regional level, following which those estimates are regressed on various regional characteristics; details are in the online appendix. Figure 3 illustrates results from this exercise by comparing trends in the relative performance of private firms in regions where Yushchenko and Yanukovich did comparatively well in the December 2004 (do-over) runoff election. ${ }^{16}$ In both parts of the country, private ownership has little impact on firm performance through 2001. The sharp acceleration after that date may be a consequence of the extensive economic reforms carried out during Yushchenko's 17-month stint as prime minister in 2000 and 2001. There is little obvious difference in the trajectories of Yushchenko and Yanukovich regions before the Orange Revolution, but trends diverge from 2004. By 2007, ownership by domestic private shareholders is estimated to have a 16-percentage-point lower impact on firm productivity in Yanukovich regions than

\footnotetext{
${ }^{16}$ Yushchenko received at least two-thirds of the vote in the 14 regions (out of 27 total) defined here as "Yushchenko regions."
} 


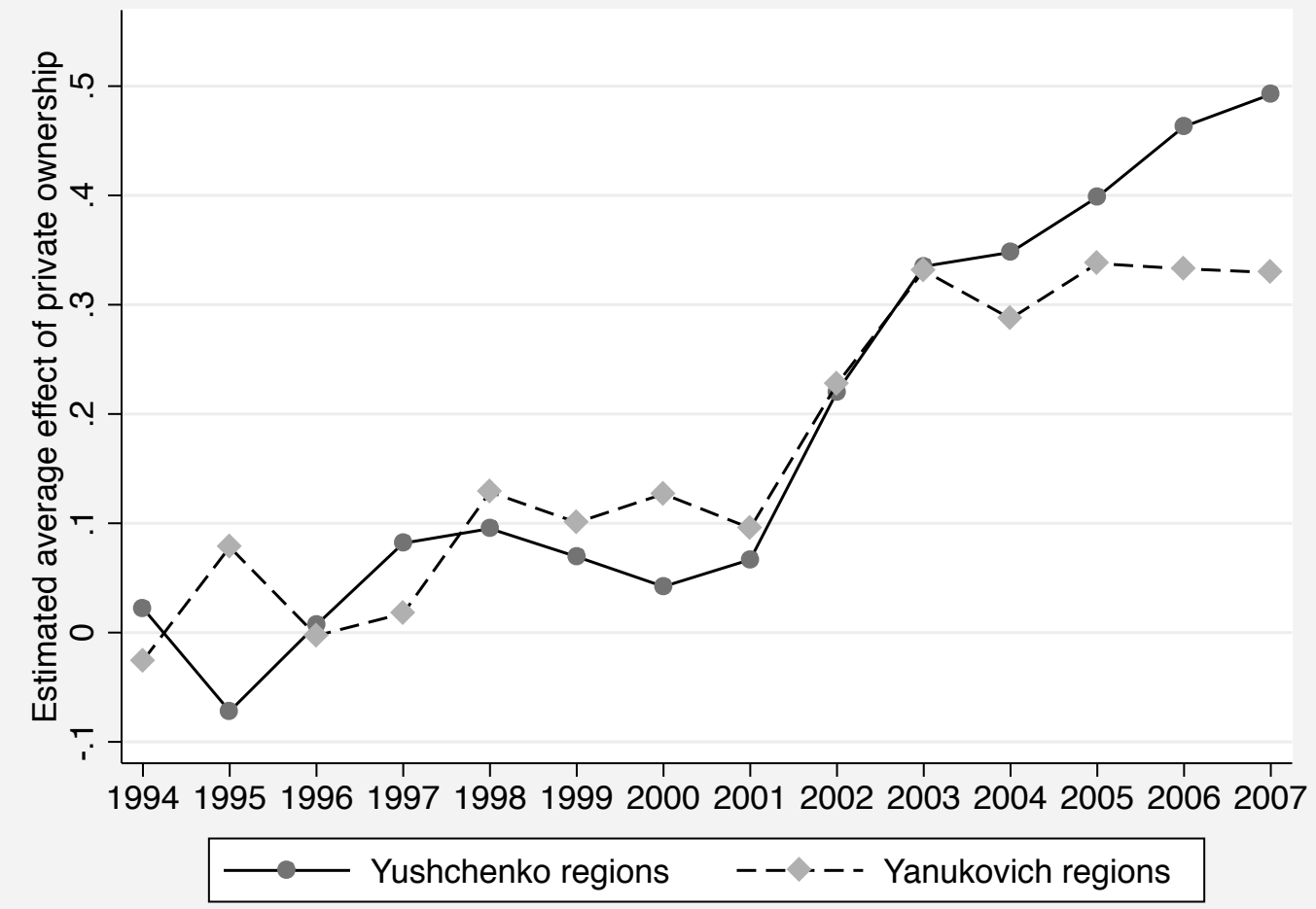

Figure 3: Average effect of private ownership on firm productivity, by year

in Yushchenko regions, a difference that is statistically significant $(p=0.054)$.

In sum, the regional shift in productivity gains following the Orange Revolution seems to have been greater for large firms, firms that are government suppliers, and private enterprises. By assumption, these actors are more sensitive to particularistic policies (though private firms may also be more sensitive to general improvements in the business climate), thus reinforcing the general interpretation of our results above.

\subsection{Decomposition}

As discussed in Section 1, some channels through which political turnover affects productivity may work through output, others through employment or investment in capital, and some through all of these variables. Reallocation of government contracts, for example, should appear in output, and perhaps also (to the extent that firms are already operating at close to full capacity) in inputs. Fear of renationalization, in turn, should reduce investment and 


\section{Table 6: Decomposition of the productivity effect}

\begin{tabular}{lccc}
\hline Dependent variable: & Output & Employment & Capital \\
\hline Post-OR $\times$ & 0.133 & -0.066 & $-0.057^{* *}$ \\
Yushchenko vote & $(0.084)$ & $(0.057)$ & $(0.026)$ \\
\hline Industry-year FEs & Yes & Yes & Yes \\
Firm fixed effects & Yes & Yes & Yes \\
Firm-specific trends & Yes & Yes & Yes \\
Ownership controls & Yes & Yes & Yes \\
\hline
\end{tabular}

Notes: All dependent variables in logs. In parentheses, heteroskedasticity-robust standard errors adjusted to allow for clustering at the regional level. Significance levels: $* * *=0.01$, $* *=0.05, *=0.10$.

restructuring, while improved government performance (more "helping," less "grabbing") should increase them.

To explore this idea, we estimate the differential impact of the Orange Revolution on the three components of productivity, as measured here: output, labor, and capital. (We refer to this exercise as "decomposition" of productivity into its components, though strictly speaking there is no decomposition of multifactor productivity, unlike labor productivity.) Table 6 presents our baseline results. Firms in Yushchenko regions experience a sizable but imprecisely estimated increase in output following the Orange Revolution, and a smaller but statistically significant decrease in capital. Productivity, of course, responds positively to marginal increases in output and decreases in inputs, but only the output result is consistent with our theoretical priors.

Although intriguing, these results mask considerable heterogeneity in the firm-level response to political turnover. The online appendix presents models in which the treatment effect is allowed to vary by type of firm, as in the estimation of heterogeneous effects above. The main finding is that the relative increase in output in Yushchenko regions following the Orange Revolution is stronger (larger in magnitude, statistically significant) for large enterprises, for firms in the equipment-supply sector, and for private enterprises. The marginal 
effect is strongest $(0.329, \mathrm{SE}=0.170)$ for firms in the second group; the negative estimated treatment effect in the capital regression in Table 6 also switches signs for such firms. This relative increase in both outputs and inputs is strong evidence for the reallocation of government contracts as a key channel through which political turnover affects productivity. Nonetheless, the similar (though smaller) results for large and private enterprises indicates that other factors may also play a role.

\section{Conclusion}

Following the 2004 Orange Revolution in Ukraine, firms in regions supportive of the new president exhibited a substantial increase in multifactor productivity, relative to firms in regions supportive of the old regime. Although the policies and channels through which this result emerged are difficult to measure and can be discerned only indirectly, our examination of possible evidence suggests that this effect was driven by particularistic rather than general economic policies, with firms in Yushchenko regions benefiting from support previously reserved for those in Yanukovich regions. This geographic pattern is most pronounced among large firms, firms in sectors that supply the government, and private enterprises, all of which had much to gain or lose from national political turnover in a context of generally weak institutions. "Decomposition" of the productivity effect into its components for various firm types indicates that reallocation of government contracts may drive much of our result, though there is room for other mechanisms.

Political turnover is often desirable. Nonetheless, the distributional consequences can be profound when institutions are weak. Oscillation of privilege from one region or sector to another is inefficient, as firms initiate or postpone restructuring based on who happens to be in power. The first-best solution is not to restrict turnover, but to make turnover safe for economic activity, which requires reforming institutions to credibly commit to equal treatment for all actors. Our results suggest that some leveling of the playing field may have indeed occurred in the years that immediately followed the Orange Revolution. Un- 
fortunately, our data extend only through 2007, prior to Viktor Yanukovich's victory in the presidential election of 2010. Anecdotal evidence suggests that Yanukovich's years in power were marked by a new turn to favoritism, which if true would imply that the institutional basis for any leveling was limited. Allegations of corruption, of course, were a major factor in the Euromaidan protests of 2013-14, which ultimately led to Yanukovich's ouster and the election of chocolate magnate Petro Poroshenko. Whether firm performance continued to respond to political turnover during these later periods is an important topic for future research. 


\section{References}

Alesina, Alberto and Roberto Perotti. 1996. "Income Distribution, Political Instability, and Investment." European Economic Review 40(6):1203-1228.

Alesina, Alberto, Sule Ozler, Nouriel Roubini and Phillip Swagel. 1996. "Political Instability and Economic Growth." Journal of Economic Growth 1(2):189-211.

Åslund, Anders. 2005. "The Economic Policy of Ukraine after the Orange Revolution." Eurasian Geography and Economics 46(5):327-353.

Åslund, Anders. 2006. The Ancien Régime: Kuchma and the Oligarchs. In Revolution in Orange: The Origins of Ukraine's Democratic Breakthrough, ed. Anders Åslund and Michael McFaul. Washington, DC: Carnegie Endowment for International Peace.

Åslund, Anders. 2009. How Ukraine Became a Market Economy and Democracy. Washington, DC: Peterson Institute for International Economics.

Baker, Scott R., Nicholas Bloom and Steven J. Davis. 2013. "Measuring Economic Policy Uncertainty." Mimeo, Stanford University.

Barro, Robert J. 1991. "Economic Growth in a Cross Section of Countries." Quarterly Journal of Economics 106(2):407-443.

Bates, Robert H. and Steven A. Block. 2013. "Revisiting African Agriculture: Institutional Change and Productivity Growth." Journal of Politics 75(2):372-384.

Beissinger, Mark R. 2007. "Structure and Example in Modular Political Phenomena: The Diffusion of Bulldozer/Rose/Orange/Tulip Revolutions." Perspectives on Politics $5(1): 259-276$.

Brown, J. David, John S. Earle and Álmos Telegdy. 2006. "The Productivity Effects of Privatization: Longitudinal Estimates from Hungary, Romania, Russia, and Ukraine." Journal of Political Economy 114(1):61-99.

Brown, J. David, John S. Earle and Scott Gehlbach. 2009. "Helping Hand or Grabbing Hand? State Bureaucracy and Privatization Effectiveness." American Political Science Review 103(2):264-283. 
Clem, Ralph S. and Peter R. Craumer. 2005. "Shades of Orange: The Electoral Geography of Ukraine's 2004 Presidential Elections." Eurasian Geography and Economics 46(5):364-385.

Denisova, Irina, Markus Eller, Timothy Frye and Ekaterina V. Zhuravskaya. 2009. "Who Wants to Revise Privatization? The Complementarity of Market Skills and Institutions." American Political Science Review 103(2):284-304.

Desai, Raj M. and Anders Olofsgard. 2011. "The Costs of Political Influence: Firm-Level Evidence From Developing Countries." Quarterly Journal of Political Science 6(2):137178.

Duvanova, Dinissa. 2013. Dinissa Duvanova. New York: Cambridge University Press.

Faccio, Mara. 2010. "Differences between Politically Connected and Non-Connected Firms: A Cross Country Analysis." Financial Management 39(3):905-927.

Ferguson, Thomas and Hans-Joachim Voth. 2008. "Betting on Hitler-The Value of Political Connections in Nazi Germany." Quarterly Journal of Economics 123(1):101-137.

Finkel, Evgeny and Yitzhak M. Brudny, eds. 2013. Coloured Revolutions and Authoritarian Reactions. London: Routledge.

Fisman, David, Raymond J. Fisman, Julia Galef, Rakesh Khurana and Yongxiang Wang. 2012. "Estimating the Value of Connections to Vice-President Cheney." The B.E. Journal of Economic Analysis \&3 Policy 13(3):Article 5.

Fisman, Raymond. 2001. "Estimating the Value of Political Connections." American Economic Review 91(4):1095-1102.

Fisman, Raymond and Jakob Svensson. 2007. "Are Corruption and Taxation Really Harmful to Growth? Firm Level Evidence." Journal of Development Economics 83(1):63-75.

Frye, Timothy. 2006. "Original Sin, Good Works, and Property Rights in Russia." World Politics 58(4):479-504.

Frye, Timothy and Andrei Shleifer. 1997. "The Invisible Hand and the Grabbing Hand." American Economic Review 87(2):354-358.

Gehlbach, Scott, Konstantin Sonin and Ekaterina Zhuravskaya. 2010. "Businessman Candi- 
dates." American Journal of Political Science 54(3):718-736.

Gorodnichenko, Yuriy and Yegor Grygorenko. 2008. "Are Oligarchs Productive? Theory and Evidence." Journal of Comparative Economics 36(1):17-42.

Guriev, Sergei and Andrei Rachinsky. 2005. "The Role of Oligarchs in Russian Capitalism." Journal of Economic Perspectives 19(1):131-150.

Haber, Stephen and Armando Razo. 1998. "Political Instability and Economic Performance: Evidence from Revolutionary Mexico.” World Politics 51(1):99-143.

Haber, Stephen, Armando Razo and Noel Maurer. 2003. The Politics of Property Rights: Political Instability, Credible Commitments, and Economic Growth in Mexico, 1876-1929. Cambridge: Cambridge University Press.

Hale, Henry E. 2005. "Regime Cycles: Democracy, Autocracy, and Revolution in Post-Soviet Eurasia." World Politics 58(1):133-165.

Hanushek, Eric A. 1974. "Efficient Estimators for Regressing Regression Coefficients." The American Statistician 28(2):66-67.

Katchanovski, Ivan. 2008. "The Orange Evolution? The 'Orange Revolution' and Political Changes in Ukraine." Post-Soviet Affairs 24(4):351-382.

Kuzio, Taras. 2005. "Ukrainian Economic Policy after the Orange Revolution: A Commentary on Åslund's Analysis." Eurasian Geography and Economics 46(5):354-363.

Kuzio, Taras. 2006. Everyday Ukrainians and the Orange Revolution. In Revolution in Orange: The Origins of Ukraine's Democratic Breakthrough, ed. Anders Åslund and Michael McFaul. Washington, DC: Carnegie Endowment for International Peace.

Londregan, John B. and Keith T. Poole. 1990. "Poverty, the Coup Trap, and the Seizure of Executive Power." World Politics 42(2):151-183.

Malesky, Edmund J. and Krislert Samphantharak. 2008. "Predictable Corruption and Firm Investment: Evidence from a Natural Experiment and Survey of Cambodian Entrepreneurs." Quarterly Journal of Political Science 3(3):227-267.

Myagkov, Mikhail, Peter C. Ordeshook and Dimitri Shakin. 2009. The Forensics of Election 
Fraud: Russia and Ukraine. New York: Cambridge University Press.

North, Douglass C., John Joseph Wallis and Barry R. Weingast. 2009. Violence and Social Orders: A Conceptual Framework for Interpreting Recorded Human History. New York: Cambridge University Press.

Paskhaver, Aleksandr and Lidiia Verkhovodova. 2007. "Privatization Before and After the Orange Revolution." Problems of Economic Transition 50(3):5-40.

Tucker, Joshua. A. 2007. "Enough! Electoral Fraud, Collective Action Problems, and PostCommunist Colored Revolutions." Perspectives on Politics 5(3):537-553.

Wilson, Andrew. 2005. Ukraine's Orange Revolution. New Haven, CT: Yale University Press.

Zhuravskaya, Ekaterina. 2007. "Whither Russia? A Review of Andrei Shleifer's A Normal Country." Journal of Economic Literature 45(1):127-146. 


\section{Appendix 1: Instrumental-variables regression}

Although our research design takes into account many correlated factors through the inclusion of firm and region fixed effects and firm-specific trends, a possible concern is that the 2004 election results could be endogenous to firm performance at the regional level. Voters may have responded positively or negatively to firm restructuring, for example, depending on how any such restructuring was carried out, and firm owners may have helped to generate votes in return for certain privileges.

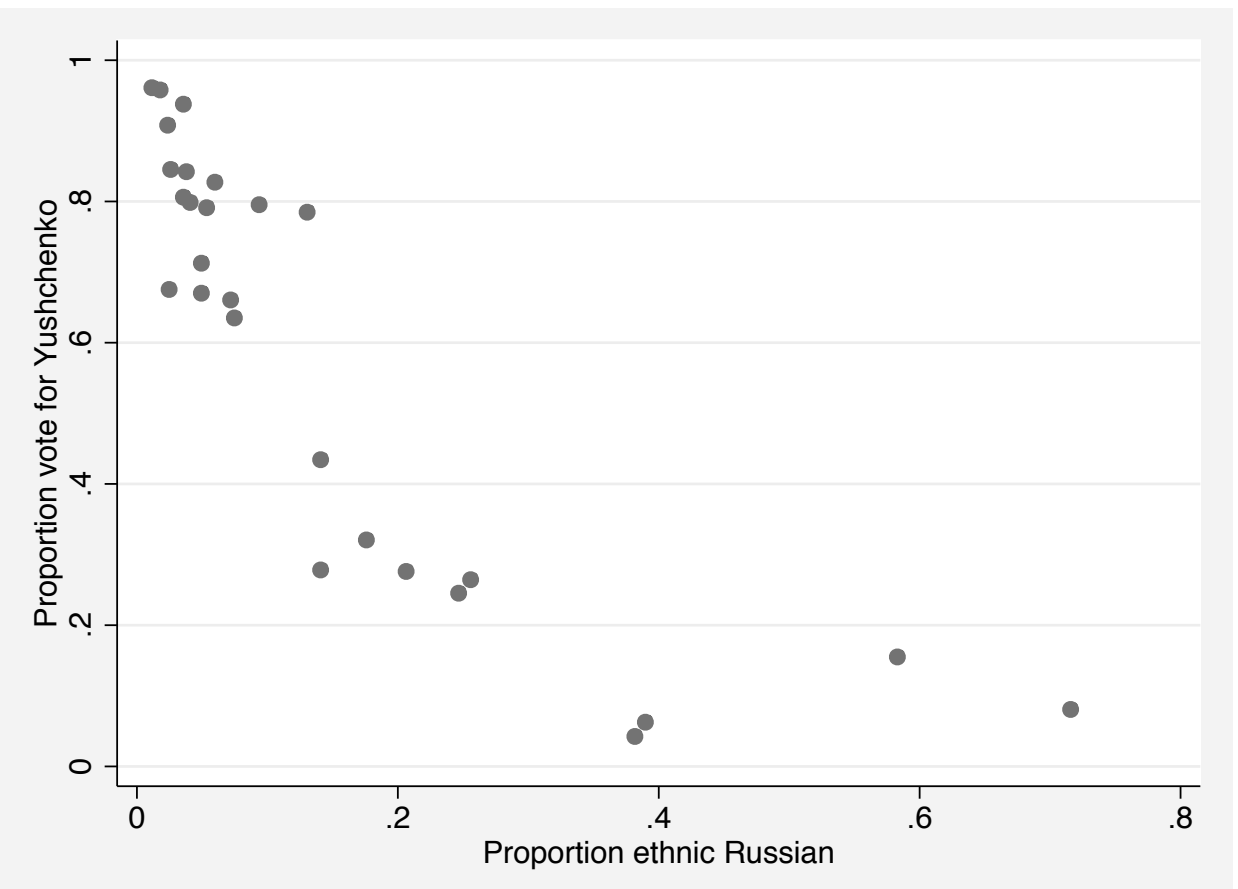

Figure A1: Voting and ethnicity

To address this concern, we exploit a striking feature of the 2004 election: the strong correlation between vote outcome and the ethnic character of the region. As shown in Figure A1, regions with large shares of self-identified Russians were overwhelmingly less likely to vote for Yushchenko in 2004. (The results we report are nearly identical if we instead use the percentage of native-Russian speakers, which is correlated with Russian ethnicity at $r=0.97$.) We thus estimate Equation 1 by two-stage least squares, where we instrument 


\section{Table A1: Instrumental-variables regression}

\begin{tabular}{lc}
\hline Post-Orange Revolution $\times$ & $0.165^{* *}$ \\
Yushchenko vote & $(0.079)$ \\
\hline Orange Revolution $\times$ & $-1.860^{* * *}$ \\
Russian ethnicity (1st stage) & $(0.296)$ \\
Kleibergen-Paap $r k$ LM test $(p$-value) & $521(0.000)$ \\
F-stat for excluded instrument & 39.444 \\
\hline Industry-year fixed effects & Yes \\
Firm fixed effects & Yes \\
Firm-specific trends & Yes \\
Ownership controls & Yes \\
\hline
\end{tabular}

Notes: The dependent variable is $\log$ (Output), and the independent variables include $\log$ (Capital) and $\log ($ Employment), with coefficients permitted to vary across industries at the two-digit level. Column (4) is an instrumental-variables regression, with the estimated coefficient on the excluded instrument reported. In parentheses, heteroskedasticity-robust standard errors adjusted to allow for clustering at the regional level. Significance levels: $* * *=0.01, * *=$ $0.05,{ }^{*}=0.10$.

$O_{t} V_{r}$ on the interaction of the dummy variable $O_{t}$ and the Russian ethnicity of the region.

For this to be a valid instrument, the ethnic identify of the region in which a firm is located should be uncorrelated with changes in firm performance other than through the effects of the Orange Revolution. Two features of our identification strategy support this assumption. First, our estimating equation (Equation 1) includes a full set of industryyear interactions as well as firm fixed effects and trends, thus controlling for the correlation between ethnicity and industrial structure at the regional level. (Russian regions have a predominance of heavy industry.) Second, the data source for Russian ethnicity is the 2001 Ukrainian Census, well prior to the Orange Revolution, when ethnic self-identification might have responded to ethnic appeals and perceptions of Russian involvement in the electoral contest.

Table A1 additionally demonstrates that the instrument is strong. The Kleibergen-Paap 
test for underidentification comfortably rejects the null that the instrument is uncorrelated with the potentially endogenous regressor. The F-statistic of 39.444, in turn, is comfortably above the critical threshold of 10 commonly used in the literature to reject the null of weak instruments.

The estimated treatment effect reported in Table A1 is large and statistically significant. The point estimate of 0.165 is only marginally smaller than that in the corresponding regression in Column 3 of Table 3. Our qualitative findings are thus robust to exploiting regional ethnicity as a plausibly exogenous source of variation in the 2004 election results.

\section{Appendix 2: State versus private ownership}

We follow the two-step approach in Brown, Earle and Gehlbach (2009), which first uses firm-level panel data to estimate the effect of private ownership on multifactor productivity at the regional level, following which those estimates are regressed on various regional characteristics. Our method differs from Brown, Earle, and Gehlbach primarily in the nature of higher-level variation that we exploit: rather than focusing on cross-sectional variation, we take advantage of a shock that affects regions differentially. Thus, we estimate time-varying regional effects of private ownership on firm performance in the first step of our two-step procedure.

Formally, we estimate the following variant of Equation 1:

$$
x_{j r s t}=f_{s}\left(k_{j r s t}, l_{j r s t}\right)+D_{j r s t} \delta_{r t}+D_{j r s t} \vartheta_{s t}+F_{j r s t} \phi+\psi_{s t}+\mathbf{w}_{t} \boldsymbol{\alpha}_{j}+\eta_{j r s t},
$$

where $D_{\text {jrst }}$ is an indicator for domestic private ownership. The region-year ownership effects $\left(\delta_{r t}\right)$ control for variation in industrial composition across regions and over time through the sector-year ownership effect $\vartheta_{s t}$. The variable $F_{j t}$ is an indicator of whether the firm was foreign-owned at the end of year $t-1$; given the very small number of foreign-privatized firms in our data set, we do not attempt to estimate a separate foreign-ownership effect for each region-year, but rather assume an effect $(\phi)$ that is constant across region-years. For conciseness, in what follows we often refer simply to estimated private-ownership effects, 
omitting the qualifier "domestic."

As discussed in Section 4, Brown, Earle and Telegdy (2006) show that estimation with firm fixed effects and firm-specific trends (i.e., $\left.\mathbf{w}_{t}=(1, t)\right)$ corrects for selection into domestic private or foreign ownership. Our estimates of regional ownership effects are therefore based on deviations resulting from privatization from the productivity trend for each individual firm, controlling for industry-year shocks. Thus, for example, private ownership would have the same impact on two firms - one in a sector experiencing rapid technological improvement, the other burdened with excess employment - if it increased productivity two percent above a positive trend in the first case and two percent above a negative trend in the second. Equation A1 allows these regional effects to vary over time - in particular, around the Orange Revolution, which occurred some years after most firms were privatized.

The estimating equation for the second step of our two-step procedure is then

$$
\hat{\delta}_{r t}=O_{t} V_{r} \chi+\mathbf{Z}_{r t} \boldsymbol{\xi}+\theta_{t}+\mathbf{w}_{t} \zeta_{r}+\varepsilon_{r t},
$$

where $\hat{\delta}_{r t}$ is the estimated region-year private-ownership effect from estimation of Equation A1. The variables $O_{t}$ and $V_{r}$ are defined as in Equation $1, \mathbf{Z}_{r t}$ is a vector of time-varying regional covariates, $\theta_{t}$ is a year fixed effect, and $\chi$ and $\boldsymbol{\xi}$ are (vectors of) coefficients to be estimated. Analogous to estimation of Equation 1, we consider two specifications of $\mathbf{w}_{t}$, with $\mathbf{w}_{t}=1$ (region fixed effects) and $\mathbf{w}_{t}=(1, t)$ (region-specific linear trends). The term $\varepsilon_{r t}$ incorporates both idiosyncratic error associated with unobserved time-varying regional characteristics and estimation error arising from firm-level estimation of $\delta_{r t}$. The latter source of error introduces heteroskedasticity of a known form, given that first-stage estimates of $\delta_{r t}$ are generally more precise in region-year cells with more firm-year observations, for which we correct by reporting heteroskedasticity-robust standard errors. (In principle, we could correct for this second-stage heteroskedasticity by employing a feasible generalized least squares [FGLS] estimator of the sort suggested by Hanushek [1974]. In practice, OLS estimation of Equation A2 is consistent, and working with similar data from Russia - with less balance across regions-Brown, Earle and Gehlbach [2009] find little difference between 
Table A2: Private ownership

\begin{tabular}{lccccc}
\hline & $(1)$ & $(2)$ & $(3)$ & $(4)$ & $(5)$ \\
\hline Post-Orange Revolution $\times$ & $0.163^{*}$ & $0.208^{* * *}$ & $0.559^{* * *}$ & $0.236^{* * *}$ & $0.265^{* * *}$ \\
Yushchenko vote & $(0.096)$ & $(0.058)$ & $(0.198)$ & $(0.062)$ & $(0.067)$ \\
Post-Orange Revolution $\times$ & & & 0.054 & & \\
western region & & & $(0.053)$ & & \\
Post-Orange Revolution $\times$ & & & $0.226^{* *}$ & & \\
southern region & & $(0.105)$ & & \\
Post-Orange Revolution $\times$ & & $0.282^{* *}$ & & \\
eastern region & & $(0.111)$ & & \\
Post-Orange Revolution $\times$ & & & -0.033 & \\
western border & & & & $0.045)$ & \\
Post-Orange Revolution $\times$ & & & & $(0.029$ & \\
eastern border & & & & Yes & Yes \\
\hline Year fixed effects & Yes & Yes & Yes & Yes \\
Region fixed effects & Yes & Yes & Yes & Yes \\
Region-specific trends & No & Yes & Yes & Yes & Yes \\
\hline Observations & 312 & 312 & 312 & 312 & 373 \\
Regions & 26 & 26 & 26 & 26 & 27 \\
\hline
\end{tabular}

Notes: Dependent variable is estimated regional effect of private ownership on firm productivity from firm-level FE\&FT regression. Heteroskedasticityrobust standard errors in parentheses. Significance levels: $* * *=0.01,{ }^{* *}=$ $0.05, *=0.10$.

\section{OLS and FGLS estimates.)}

Table A2 presents results from the second step of this two-step procedure. For most specifications, we report results for a balanced panel of estimated private-ownership effects from 1996 through 2007, as there are relatively few privatizations prior to 1996, and we drop Sevastopol from the analysis, as there are very few firm-year observations in that region (city). Column 5 extends the panel to include these estimated region-year effects. The results show a robustly larger impact of the Orange Revolution on privately owned firms, consistent with the idea that the defeat of Yanukovich may have particularly threatened the property rights of private owners connected to the old regime or that the incentives of private owners are more sensitive to general changes in the business climate. 


\section{Appendix 3: Decomposition}

The following tables present additional results from our decomposition exercise. 


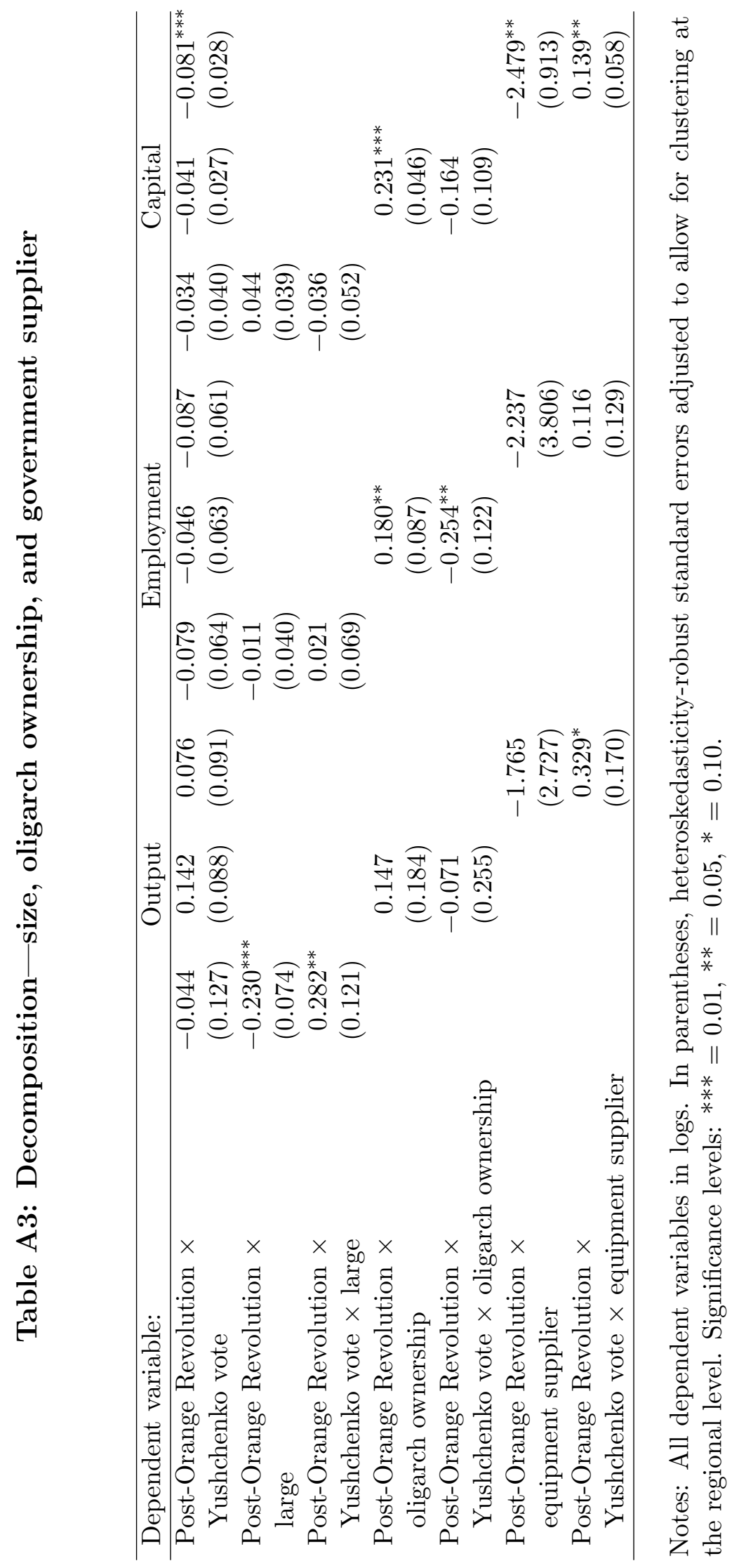


Table A4: Decomposition-private ownership

\begin{tabular}{lccc}
\hline Dependent variable: & Output & Employment & Capital \\
\hline Post-Orange Revolution $\times$ & $0.175^{* * *}$ & -0.032 & $-0.056^{*}$ \\
Yushchenko vote & $(0.064)$ & $(0.037)$ & $(0.029)$ \\
\hline Year fixed effects & Yes & Yes & Yes \\
Region fixed effects & Yes & Yes & Yes \\
Region-specific trends & Yes & Yes & Yes \\
\hline Observations & 312 & 312 & 312 \\
Regions & 26 & 26 & 26 \\
\hline
\end{tabular}

Notes: Dependent variable is estimated regional effect of private ownership on firm productivity from firm-level FE\&FT regression. Heteroskedasticityrobust standard errors in parentheses. Significance levels: ${ }^{* * *}=0.01,{ }^{* *}=$ $0.05,{ }^{*}=0.10$. 